\title{
Impact of Lean Implementation on Employees' Job Satisfaction in the ABC Apparel Manufacturing Firm
}

\author{
Navodhika Karunarathne $^{1}$, H. M. U. S. R. Samarasinghe ${ }^{1}$ \\ ${ }^{1}$ SLIIT Business School, Malabe, Sri Lanka \\ Correspondence: H. M. U. S. R. Samarasinghe, SLIIT Business School, Malabe, Sri Lanka.
}

Received: September 23, 2019

Accepted: October 16, 2019 Online Published: October 21, 2019

doi:10.5539/ibr.v12n11p48

URL: https://doi.org/10.5539/ibr.v12n11p48

\begin{abstract}
For almost all organizations, employees are the vital resource and they are representing an important asset within the business. The main concern of Human resource management is to improve the potential of employees so that they can get maximum job satisfaction from their work and give their best efforts to the organization. Job satisfaction represents one of the foremost areas facing current managers when it comes to managing their employees. In the current context of Sri Lankan apparel industry, it can be seen that the high labor turnover rate in relation to the labor recruitments. The lean implementation of the apparel industry has been drastically changing the industrial environment and the way a worker perform his job role. As a solution to the labor turnover it is necessary to identify the impact of lean implementation on the employee satisfaction.

$\mathrm{ABC}$ apparel manufacturing firm is a one of the apparel manufacturing firms which has implemented lean concepts such as Empowerment, Standardization, Quality Management, Problem Solving Demand, Effort-Reward Fairness, Team Working Culture and Job Rotation. Based on the literature review and preliminary investigation, hypothesis were developed in order to identify the relationship between the lean implementation and job satisfaction. Therefore the primary data for this research were collected through the survey conducted in the ABC Company. The survey was conducted over 60 sample units and the sample was selected using the simple random sampling technique. The collected data were analyzed using the statistical tool namely descriptive statistics, frequencies, correlation and linear regression. Based on the data analysis, it can be concluded that there is a moderate positive relationship between the lean practices and the job satisfaction in the $\mathrm{ABC}$ apparel manufacturing firm.
\end{abstract}

Keywords: lean implementation, job satisfaction, empowerment, standardization, quality management, problem solving demand, effort-reward fairness, team working culture and job rotation

\section{Introduction}

For almost all organizations, employees are the vital resource and they are representing an important asset within the business. The main concern of Human resource management is to improve the potential of employees so that they can get maximum job satisfaction from their work and give their best efforts to the organization. "Almost every country irrespective of its stage of development, is engaged in garment manufacturing and trading and almost, without any exception, historically, the readymade industry was the first industry country was able to introduce which eventually led to the development of other industries" (Huda, Akhtar and Akhtar 2011).In Sri Lanka also, apparel industry has been contributing significantly to the national economy. According to the Dheerasinghe (2009), apparel industry has become Sri Lanka's leading export industry since 1986. "It is also the country's prime net foreign exchange generator since 1992 “(Kelegama and Foley 1999).

The focus of lean manufacturing in recent years has broadened beyond shop-floor tools to the lean principles which incorporate the notion of value and waste elimination into the production system (Womack and Jones, 1994). Due to the increased pressure on organizations to attain competitive advantage in terms of their product cost, service, and quality, it has led to the establishment of lean manufacturing as its widely demonstrated positive impact on operational performance. With the rapid change happening in the apparel industry such as dynamic fashion designs, varying order quantities and increasing quality levels at lowest possible cost, demand the apparel manufacturer to be concentrated on more effective and efficient manufacturing processes for survival in vastly competitive market. "The necessity of reducing cost of production has left manufacturers with the challenge of adopting lean manufacturing where the focus is on waste minimization" (J.R., et al. 2012). 
Over the last few decades, employee satisfaction has been a significant area of research among the industrial psychologists. It can be considered as a combination of positive or negative feelings that workers possess towards their work. "Job satisfaction represents the extent to which expectations matched with the real awards. And it is closely linked to that individual's behavior in the work place" (Davis et al., 1985). Employee absenteeism and turnover cause huge additional costs for companies, hence managers continuously examine of ways how to decrease it to its minimum. Probably, the best way to reduce employee absenteeism and turnover would be through an increase in the level of employee satisfaction. The main idea behind this approach is that the higher the degree of job satisfaction is the lower employee absenteeism and turnover should be.

In the present context of Sri Lankan apparel industry, it can be seen that the high labor turnover rate in relation to the labor recruitments. The lean implementation of the apparel industry has been drastically changing the industrial environment and the way a worker perform his job roles. As a solution to the labor turnover it is necessary to identify the impact of lean implementation on the employee satisfaction. There has been an argument that human resource practices that is resultant from lean implementation such as teamwork, rewarding for higher performance, regular feedback, training, focus on customer value, active participation in continuous improvement and decision-making activities can positively change perceived job autonomy and how employees evaluate their jobs. Consequently, employees can experience an increase in their job satisfaction. In order to prove that fact this research study is conducted based on a leading apparel manufacturing facility which has already implemented the lean concepts.

\section{Literature Review}

This section depicts a summary of systematic review of literature related to the research title, which supported the justification of the study area. It was conducted under few topics such as Lean Implementation in Apparel Industry, Effect of Lean on Job Satisfaction, Job satisfaction, Job Satisfaction in Apparel Industry and HR and Lean Integration. Following few tables represents the key findings of the literature review.

Table 1. Summary of the Literature Review

\begin{tabular}{|c|c|c|c|}
\hline \multirow[t]{2}{*}{ Authors } & \multicolumn{2}{|l|}{ Variables } & \multirow[t]{2}{*}{ Findings } \\
\hline & Independent & Dependent & \\
\hline $\begin{array}{ll}\text { Sim, } & \text { Curatola } \\
\text { and } & \text { Banerjee } \\
2015) & \end{array}$ & 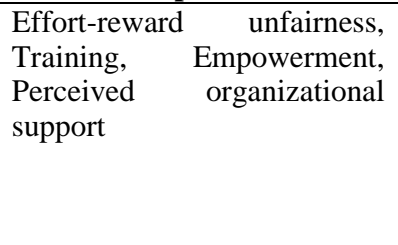 & $\begin{array}{l}\text {-Job Satisfaction } \\
\text {-Job Security }\end{array}$ & $\begin{array}{l}\text {-The positive motivational effects of suggestion } \\
\text { autonomy tend to have on the workers' wellbeing } \\
\text { - The signaling effect of overall satisfaction by the } \\
\text { workers can be used to gauge a firm before it moves } \\
\text { in the direction of excessive leanness, decreased } \\
\text { employee satisfaction and suboptimal system } \\
\text { performance. }\end{array}$ \\
\hline $\begin{array}{l}\text { (Cullinane } \\
\text { 2012) }\end{array}$ & $\begin{array}{l}\text { Job design under lean } \\
\text { manufacturing }\end{array}$ & $\begin{array}{l}\text {-Employee } \\
\text { outcomes } \\
\text {-Employee } \\
\text { well-being }\end{array}$ & $\begin{array}{l}\text { - Investigates how jobs can be enriched within lean } \\
\text { manufacturing organizations. }\end{array}$ \\
\hline $\begin{array}{l}\text { (J.R., et al. } \\
2012)\end{array}$ & Lean Manufacturing & $\begin{array}{l}\text { Performance and } \\
\text { Organizational } \\
\text { Culture }\end{array}$ & $\begin{array}{l}\text { - Organizations in the bulk apparel production } \\
\text { industry could achieve positive cultural shift and } \\
\text { gain financial benefits as well through } \\
\text { implementation of lean manufacturing practices }\end{array}$ \\
\hline $\begin{array}{l}\text { (Rodríguez } \\
\text { 2015) }\end{array}$ & Employee-supportive Lean & $\begin{array}{l}\text {-Operational } \\
\text { performance } \\
\text {-Employees' } \\
\text { perceived Job } \\
\text { autonomy } \\
\text {-Job satisfaction }\end{array}$ & $\begin{array}{l}\text {-A positive impact of employee-supportive Lean on } \\
\text { perceived job autonomy and job satisfaction and a } \\
\text { positive relationship between perceived job } \\
\text { autonomy and job satisfaction, and job satisfaction } \\
\text { and operational performance. }\end{array}$ \\
\hline $\begin{array}{l}\text { (Bouville and } \\
\text { Alis 2014) }\end{array}$ & Lean organizational practices & $\begin{array}{l}\text {-Employees' } \\
\text { attitudes } \\
\text {-Workers' health } \\
\text {-Job Satisfaction }\end{array}$ & $\begin{array}{l}\text {-Negative consequences of several lean work } \\
\text { organization practices (delegation of responsibilities, } \\
\text { problem-solving demand, standardization, job } \\
\text { rotation) on job satisfaction, employees' intention to } \\
\text { stay and health at work } \\
\text { - Quality management is positively linked to health } \\
\text { at work. } \\
\text {-Lean work organization practices, as a bundle, have } \\
\text { a deleterious effect on attitudes and health at work }\end{array}$ \\
\hline (Vidal 2007) & $\begin{array}{l}\text { Lean Production, Worker } \\
\text { Empowerment }\end{array}$ & Job Satisfaction & $\begin{array}{l}\text { - Workers can be satisfied under relatively } \\
\text { traditional Fordist arrangements and that increasing } \\
\text { employee involvement does not necessarily increase }\end{array}$ \\
\hline
\end{tabular}




\begin{tabular}{|c|c|c|c|}
\hline & & & satisfaction. \\
\hline $\begin{array}{l}\text { (AZIRI 2011) } \\
\text { Literature } \\
\text { Review }\end{array}$ & Diverse Factors & Job Satisfaction & $\begin{array}{l}\text {-Provides diverse definitions on Job Satisfaction and } \\
\text { Factors affecting Job Satisfaction, Importance and } \\
\text { Measurements of Job Satisfaction, Effect of Job } \\
\text { Satisfaction }\end{array}$ \\
\hline $\begin{array}{ll}\text { (Huda, } & \text { Akhtar } \\
\text { and } & \text { Akhtar } \\
2011) & \end{array}$ & $\begin{array}{l}\text { Current salary, working } \\
\text { environment, present health } \\
\text { care facility, safety facilities, } \\
\text { overtime } \\
\text { benefits, leave policy, } \\
\text { promotion policies, behavior } \\
\text { of the owner }\end{array}$ & $\begin{array}{l}\text { Employee job } \\
\text { satisfaction }\end{array}$ & $\begin{array}{l}\text {-Garment workers are unhappy with their working } \\
\text { environment and about pay package (based a study } \\
\text { on Garments Industry in Bangladesh) }\end{array}$ \\
\hline $\begin{array}{l}\text { (Dr.U.Vani and } \\
\text { P.Janani 2016) }\end{array}$ & $\begin{array}{l}\text { Organizational factors, } \\
\text { Group Factors , } \\
\text { Individual factors }\end{array}$ & Job satisfaction & $\begin{array}{l}\text { - Payment of wages and salary are satisfied, } \\
\text { proceeding to co- workers relationship are cordial, } \\
\text { Working conditions are satisfied and Promotion } \\
\text { opportunities are satisfied are ranked as second, third } \\
\text { and fourth, followed by Jobs security, Company } \\
\text { policies and rules and Training and development are } \\
\text { satisfied respectively. }\end{array}$ \\
\hline $\begin{array}{l}\text { (Shukla and } \\
\text { Ashish 2016) }\end{array}$ & $\begin{array}{l}\text { Working conditions, Pay and } \\
\text { related policies, Skills and } \\
\text { Development , Promotion } \\
\text { and supervision }\end{array}$ & $\begin{array}{l}\text { Employee } \\
\text { Satisfaction }\end{array}$ & $\begin{array}{l}\text { - Key factors affecting employees' satisfaction at } \\
\text { Batswana Garments are working conditions, pay and } \\
\text { related policies, performance and reward policies, } \\
\text { promotion policies and training and development } \\
\text { opportunities. }\end{array}$ \\
\hline $\begin{array}{l}\text { (De Silva, et al. } \\
\text { 2016) }\end{array}$ & Lean Concepts & $\begin{array}{l}\text { Human } \\
\text { Resourcing } \\
\text { Practice }\end{array}$ & $\begin{array}{l}\text {-Applicability of lean concept in improving the } \\
\text { human resourcing practice in the context of Sri } \\
\text { Lankan apparel industry has been identified. }\end{array}$ \\
\hline $\begin{array}{l}\text { (Bonavia and } \\
\text { Marin-Garcia } \\
\text { 2011) }\end{array}$ & Lean Production (LP) & $\begin{array}{l}\text { Human Resource } \\
\text { Management }\end{array}$ & $\begin{array}{l}\text {-Combination of LP with HRM practices reduces } \\
\text { inventory and boosts productivity but does not } \\
\text { appear to affect the other performance variables } \\
\text { analyzed. }\end{array}$ \\
\hline $\begin{array}{l}\text { (Juradoa, } \\
\text { al.2013) }\end{array}$ & $\begin{array}{l}\text { Human } \\
\text { Management }\end{array}$ & $\begin{array}{l}\text { Lean Production } \\
\text { Adoption }\end{array}$ & $\begin{array}{l}\text {-Success factors in HRM during the transition } \\
\text { process to Lean Production: the setting up of joint } \\
\text { management-trade unions committees, training, } \\
\text { communication, rewards ,job design and work } \\
\text { organization }\end{array}$ \\
\hline $\begin{array}{l}\text { (Byfuglien, et } \\
\text { al. 2010) }\end{array}$ & Lean & $\begin{array}{l}\text { Human Resource } \\
\text { Management }\end{array}$ & $\begin{array}{l}\text {-Lean implies a bottom-up approach; it requires } \\
\text { empowerment and involvement of all employees and } \\
\text { a new type of leadership. }\end{array}$ \\
\hline $\begin{array}{l}\text { (Boztınaztepe } \\
2008)\end{array}$ & Lean Tools & $\begin{array}{l}\text { Production Time } \\
\text { and } \\
\text { Employees } \\
\text { Satisfaction }\end{array}$ & $\begin{array}{l}\text { - Employees are under effect of work area and } \\
\text { employees were satisfied after } 5 \mathrm{~S} \text { implementation, } \\
\text { also production time will be reduced at least one } \\
\text { hour in the length of time. }\end{array}$ \\
\hline $\begin{array}{l}\text { (Grobelny and } \\
\text { Ewelina 2012) }\end{array}$ & $\begin{array}{l}\text { Lean Management } \\
\text { Application }\end{array}$ & $\begin{array}{ll}\text { Readiness for } \\
\text { change and job } \\
\text { satisfaction }\end{array}$ & $\begin{array}{l}\text { Employees from the lean manufacturing company in } \\
\text { comparison with employees from the mass } \\
\text { production company were characterized by higher } \\
\text { level of cognitive readiness for change, } \\
\text { resourcefulness and confidence, positive affect at } \\
\text { work and overall job satisfaction. }\end{array}$ \\
\hline (MINH 2012) & $\begin{array}{l}\text { Lean } \\
\text { Practices }\end{array}$ & Job Satisfaction & $\begin{array}{l}\text {-Lean manufacturing practices have partial positive } \\
\text { effect on job characteristics and job satisfaction. } \\
\text {-Job characteristics have significant positive effects } \\
\text { on job satisfaction. } \\
\text {-Job characteristics have partially mediated the } \\
\text { relationship between lean manufacturing practices } \\
\text { and job satisfaction. } \\
\text { - Lean culture has partial moderating effects on the } \\
\text { relationship between lean manufacturing practices } \\
\text { and job satisfaction. }\end{array}$ \\
\hline
\end{tabular}


Table 2. Definitions for the Job Satisfaction

\begin{tabular}{ll}
\hline \multicolumn{1}{c}{ Authors } & \multicolumn{1}{c}{ Definition } \\
\hline (Hoppock, 1935) & $\begin{array}{l}\text { "Any combination of psychological, physiological and environmental } \\
\text { circumstances that cause a person truthfully to say I am satisfied with my job" }\end{array}$ \\
\hline (Vroom, 1964). & $\begin{array}{l}\text { "Affective orientations on the part of individuals toward work roles which they are presently } \\
\text { occupying." }\end{array}$ \\
\hline (Davis et al., 1985). & "A combination of positive or negative feelings that workers have towards their work." \\
\hline (Kaliski,2007) & $\begin{array}{l}\text { "A worker's sense of achievement and success on the job" } \\
\text { "Doing a job one enjoys, doing it well and being rewarded for one's efforts" } \\
\text { "Enthusiasm and happiness with one's work." } \\
\text { " The key ingredient that leads to recognition, income, promotion, and the achievement of other } \\
\text { goals that lead to a feeling of fulfillment" }\end{array}$ \\
\hline "Statt, 2004). & $\begin{array}{l}\text { "The extent to which a worker is content with the rewards he or she gets } \\
\text { "The attitude and feelings people have about their work. " } \\
\text { "Positive and favorable attitudes towards the job indicate job satisfaction" }\end{array}$ \\
\hline (Armstrong, 2006). & $\begin{array}{l}\text { "The collection of feeling and beliefs that people have about their current job." } \\
\text { al., 2008) }\end{array}$ \\
\hline (Mullins, 2005). & $\begin{array}{l}\text { "A complex and multifaceted concept which can mean different things to different people" } \\
\text { "A personal feeling of achievement, either quantitative or qualitative" }\end{array}$ \\
\hline (Aziri, 2008). & "An internal state that results from the affective and cognitive evaluation of the job" \\
\hline (Brief, 1998). &
\end{tabular}

Table 3. Factors Affecting the Job Satisfaction

\begin{tabular}{|c|c|}
\hline Authors & $\begin{array}{l}\text { Factors Affecting the Job Satisfaction } \\
\end{array}$ \\
\hline (Christen Et, 2006) & Job related factors, Role perceptions, Job performance \\
\hline (Lawler and Porter, 1967) & Intrinsic and Extrinsic Rewards \\
\hline (Rue and Byaes, 2003) & $\begin{array}{l}\text { Manager's concern for people, Job design (scope, depth, interest, perceived value), } \\
\text { Compensation (external and internal consistency), Working conditions, Social } \\
\text { relationships, Perceived long-range opportunities, Perceived opportunities elsewhere, } \\
\text { Levels of aspiration and need achievement }\end{array}$ \\
\hline \multirow[t]{2}{*}{ (Herzberg, 1976) } & $\begin{array}{l}\text { Hygiene Factors : Company policies, Supervision ,Interpersonal relations ,Work } \\
\text { conditions Salary, Status ,Job security }\end{array}$ \\
\hline & $\begin{array}{l}\text { Motivators : Achievement, Recognition, Work itself, Responsibility, Advancement, } \\
\text { Growth }\end{array}$ \\
\hline $\begin{array}{l}\text { (Huda, Akhtar and Akhtar } \\
\text { 2011) }\end{array}$ & $\begin{array}{l}\text { Current salary, Working environment, Present health care facility, Safety facilities, } \\
\text { Overtime benefits, Leave policy, Promotion policies, Behavior of the owner }\end{array}$ \\
\hline (Dr.U.Vani and P.Janani 2016) & $\begin{array}{l}\text { Organizational Factors -Pay (wages), Opportunities for promotion, Nature of work, } \\
\text { Policies of organization and Working conditions. } \\
\text { Group Factors - Group size \& Supervision } \\
\text { Individual Factors - Self- respect, Status }\end{array}$ \\
\hline (Shukla and Ashish 2016) & $\begin{array}{l}\text { Working conditions, Pay and related policies, Skills and Development, Promotion \& } \\
\text { supervision }\end{array}$ \\
\hline
\end{tabular}

\section{Methodology}

This research study commenced with preliminary investigation conducted in the $\mathrm{ABC}$ apparel manufacturing plant and then the literature review was done to develop the conceptual framework and hypothesis. 


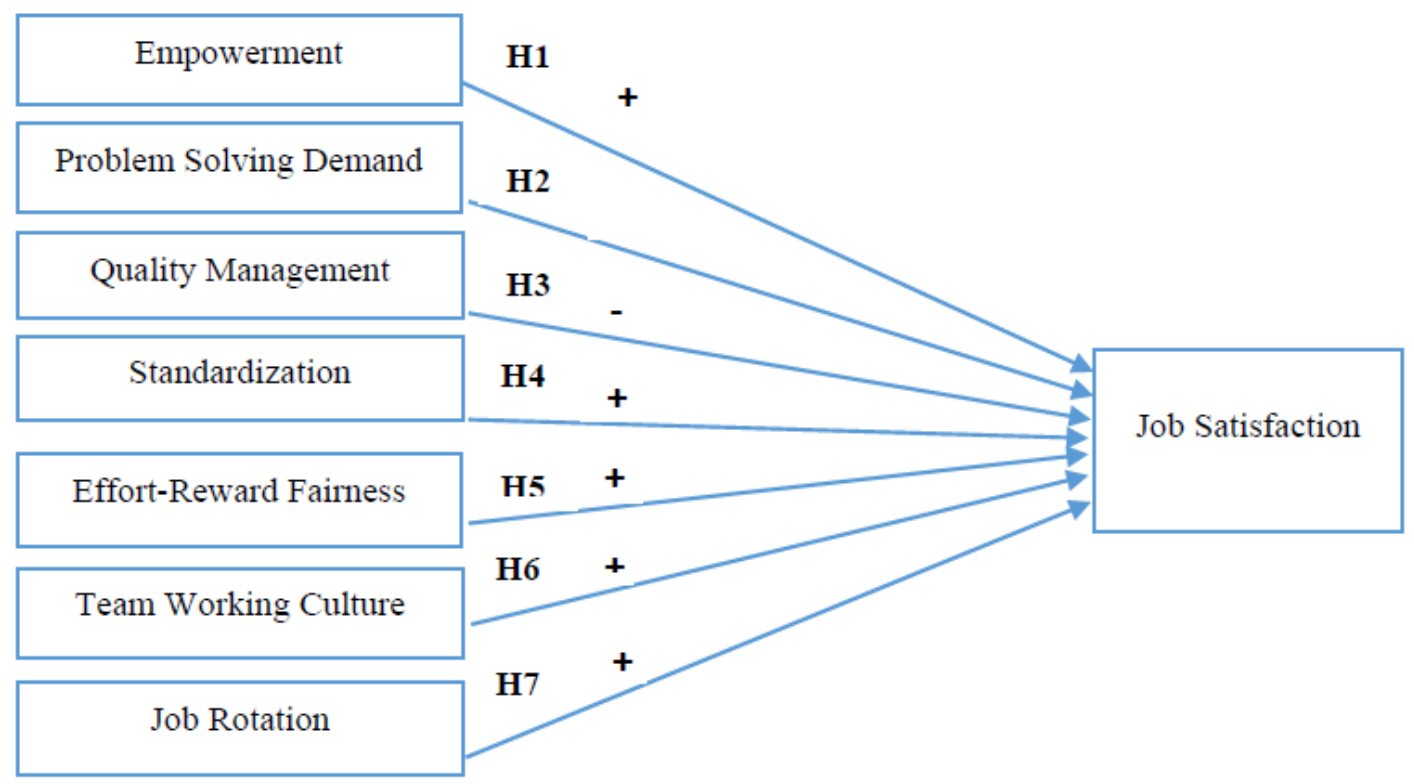

Figure 1. Conceptual Framework

In identifying the impact of lean practices in any organization, it is essential to have industry specific indicators. Important lean concepts that are being generally used in the apparel sector have been identified from the literature such as Empowerment, Standardization, Quality Concerns Problem Solving Demand, Reward System, Team Working Culture and Job Rotation. After the preliminary investigation, the lean practices which are actually implemented by the $\mathrm{ABC}$ apparel firm were identified. Then the appropriated practices were selected as the independent variables and the following hypothesis were built referring the relevant literature also.

H1: Empowerment resultant from lean implementations is positively related to the Job Satisfaction.

H2: Problem-solving demand resultant from lean implementations is negatively related to the Job Satisfaction.

H3: Quality Concerns resultant from lean implementations is negatively related to the Job Satisfaction.

H4: Standardization resultant from lean implementations is positively related to the Job Satisfaction.

H5: Reward System resultant from lean implementations is positively related to the Job Satisfaction.

H6: Team Working Culture resultant from lean implementations is positively related to the Job Satisfaction.

H7: Job rotation is positively related to job satisfaction.

All machine operators in the production floor of the $\mathrm{ABC}$ apparel manufacturing plant can be identified as the population for the survey. The total shop floor workers in this organization is 197 . The research was conducted over 60 sample units and the sample will be selected using the simple random sampling technique. Sample size of 60 was selected for the primary data sampling as universe is of 197 employees which is nearly about $30 \%$ as recommended in the research scales of job satisfaction measurements.

The survey questionnaire was designed in such a way that it analyses the level of job satisfaction of the employees in the company. It included 21 statements that ask for employees' level of agreement with close-ended questions. A pilot study has been conducted in order to measure the reliability of the variables. In this study, ten sample questionnaires were circulated among 10 undergraduates to test the questions and desired outcome as a pilot test to measure the validity and reliability of the questionnaire. The workers completed the survey in the company's meeting room and returned it on the same day. Apart from data collection through questionnaire, researchers got opportunity to meet three resource persons such as HR manager, Production manager and the Quality manager. The collected data were analyzed using descriptive statistics and statistical analysis tool namely percentage testing method (frequency), correlation and linear regression.

\section{Findings}

When it is considered the years of employments of respondents, $46.6 \%$ of the respondents ( 28 employees) have 
spent 5 years or less with the company, $38.3 \%$ of the respondents (23 employees) have spent 5-10 years of employment and $15 \%$ of the respondents ( 9 employees) have 11 or more. Among the participants, 44 employees are female $(73.3 \%)$ and 16 employees $(26.6 \%)$ are male. There is a high percentage of female employees can be seen in the $\mathrm{ABC}$ apparel firm. Therefore, it can be concluded that the selected sample represents the appropriate figure of population. The participants were categorized into the four main age groups such as 18-25 (21 employees), 26-35 (25 employees), 35-50 (9 employees) and more than 50 (5 employees).Following descriptive statistics are quantitatively describing the variables through characterizing the constructs and main features of the collected data.

Table 4. Descriptive Statistics of Survey Responses

\begin{tabular}{lrrrrr}
\hline & \multicolumn{7}{c}{ Descriptive Statistics } \\
\hline & N & \multicolumn{1}{c}{ Minimum } & Maximum & Mean & Std. Deviation \\
\hline Empowerment & 60 & 1.00 & 3.00 & 1.7333 & .60693 \\
Problem Solving Demand & 60 & 1.00 & 4.00 & 2.3833 & .86537 \\
Quality Mgmt & 60 & 1.00 & 4.00 & 2.2000 & .87914 \\
Standardization & 60 & 1.00 & 3.00 & 1.7333 & .68561 \\
Effort-Reward Fairness & 60 & 1.00 & 4.00 & 1.8667 & 1.04908 \\
Team Working Culture & 60 & 1.00 & 4.00 & 1.8000 & 1.02180 \\
Job Rotation & 60 & 1.00 & 5.00 & 3.3167 & 1.12734 \\
Overall Lean Practices & 60 & 1.00 & 4.00 & 2.1667 & .86684 \\
Valid N (listwise) & 60 & & & & \\
\hline
\end{tabular}

Following table represents the responses given by the participants for each respective variable.

Table 5. Frequencies of Survey Responses

\begin{tabular}{lccccc}
\hline \multicolumn{1}{c}{ Variable } & $\begin{array}{c}\text { Highly } \\
\text { Agree }\end{array}$ & Agree & Moderate & Disagree & $\begin{array}{c}\text { Highly } \\
\text { Disagree }\end{array}$ \\
\hline Empowerment/ Perceived Level of Responsibility and & 35 & 56.7 & 8.3 & & \\
Job Satisfaction & 23.3 & 16.7 & 58.3 & 1.7 & \\
Problem Solving Demand and Job Satisfaction & 26.7 & 30 & 40 & 3.3 \\
$\begin{array}{l}\text { Quality Management and Job Satisfaction } \\
\text { Standardization and Job Satisfaction }\end{array}$ & 40 & 46.7 & 13.3 & & \\
Reward System/ Effort-Reward Fairness and Job & 50 & 25 & 13.3 & 11.7 & \\
Satisfaction & 55 & 18.3 & 18.3 & 8.3 & \\
Team Working Culture and Job Satisfaction & 8.3 & 16.7 & 20 & 45 & 10 \\
Job Rotation and Job Satisfaction & 23.3 & 43.3 & 26.7 & 6.7 & \\
Lean Implementation and Overall Job Satisfaction & & & & & \\
\hline
\end{tabular}

Table 6. Correlation Matrix

\begin{tabular}{|c|c|c|c|c|c|c|c|c|c|}
\hline & & $\begin{array}{c}\text { Mean } \\
\text { (Empo } \\
\text { werme } \\
\text { nt) }\end{array}$ & $\begin{array}{c}\text { Mean } \\
\text { (Problem } \\
\text { Solving } \\
\text { Demand) }\end{array}$ & $\begin{array}{c}\text { Mean } \\
\text { (Qualit } \\
\text { y } \\
\text { Manag } \\
\text { ement) }\end{array}$ & $\begin{array}{c}\text { Mea } \\
n \\
\text { (Sta } \\
\text { ndar } \\
\text { dizat } \\
\text { ion) }\end{array}$ & $\begin{array}{c}\text { Mean } \\
\text { (Effort } \\
\text { Rewar } \\
\text { d } \\
\text { Fairne } \\
\text { ss) }\end{array}$ & $\begin{array}{c}\text { Mea } \\
n \\
(\text { Tea } \\
\text { m } \\
\text { Wor } \\
\text { king } \\
\text { Cult } \\
\text { ure) }\end{array}$ & $\begin{array}{c}\text { Mean } \\
\text { (Job } \\
\text { Rotati } \\
\text { on) }\end{array}$ & $\begin{array}{c}\text { Mea } \\
n \\
\text { (Sat } \\
\text { isfa } \\
\text { ctio } \\
\text { n) }\end{array}$ \\
\hline \multirow{3}{*}{$\begin{array}{l}\text { Mean } \\
\text { (Empower } \\
\text { ment) }\end{array}$} & $\begin{array}{l}\text { Pearson } \\
\text { Correlation }\end{array}$ & 1 & .229 & .112 & .052 & .111 & .250 & .153 & .752 \\
\hline & Sig. (2-tailed) & & .078 & .395 & .694 & .400 & .054 & .242 & .447 \\
\hline & $\mathrm{N}$ & 60 & 60 & 60 & 60 & 60 & 60 & 60 & 60 \\
\hline \multirow{3}{*}{$\begin{array}{l}\text { Mean } \\
\text { (Problem } \\
\text { Solving } \\
\text { Demand) } \\
\end{array}$} & $\begin{array}{l}\text { Pearson } \\
\text { Correlation }\end{array}$ & .229 & 1 & $.279^{*}$ & .052 & .000 & .160 & .009 & .218 \\
\hline & Sig. (2-tailed) & .078 & & .031 & .695 & 1.000 & .223 & .943 & .094 \\
\hline & $\mathrm{N}$ & 60 & 60 & 60 & 60 & 60 & 60 & 60 & 60 \\
\hline \multirow{3}{*}{$\begin{array}{l}\text { Mean } \\
\text { (Quality } \\
\text { Manageme } \\
\text { nt) }\end{array}$} & $\begin{array}{l}\text { Pearson } \\
\text { Correlation } \\
\end{array}$ & .112 & $.279^{*}$ & 1 & .076 & .048 & .187 & .116 & .510 \\
\hline & Sig. (2-tailed) & .395 & .031 & & .564 & .716 & .154 & .376 & .495 \\
\hline & $\mathrm{N}$ & 60 & 60 & 60 & 60 & 60 & 60 & 60 & 60 \\
\hline $\begin{array}{l}\text { Mean } \\
\text { (Standardi }\end{array}$ & $\begin{array}{l}\text { Pearson } \\
\text { Correlation }\end{array}$ & .052 & .052 & .076 & 1 & .013 & .064 & .046 & .710 \\
\hline
\end{tabular}




\begin{tabular}{|c|c|c|c|c|c|c|c|c|c|}
\hline \multirow[t]{2}{*}{ zation) } & Sig. (2-tailed) & .694 & .695 & .564 & & .921 & .626 & .726 & .939 \\
\hline & $\mathrm{N}$ & 60 & 60 & 60 & 60 & 60 & 60 & 60 & 60 \\
\hline \multirow{3}{*}{$\begin{array}{l}\text { Mean } \\
\text { (Effort } \\
\text { Reward } \\
\text { Fairness) }\end{array}$} & $\begin{array}{l}\text { Pearson } \\
\text { Correlation }\end{array}$ & .111 & .000 & .048 & .013 & 1 & .149 & .199 & .827 \\
\hline & Sig. (2-tailed) & .400 & 1.000 & .716 & .921 & & .255 & .128 & .334 \\
\hline & $\mathrm{N}$ & 60 & 60 & 60 & 60 & 60 & 60 & 60 & 60 \\
\hline \multirow{3}{*}{$\begin{array}{l}\text { Mean } \\
\text { (Team } \\
\text { Working } \\
\text { Culture) } \\
\end{array}$} & $\begin{array}{l}\text { Pearson } \\
\text { Correlation }\end{array}$ & .250 & .160 & .187 & .064 & .149 & 1 & .231 & .745 \\
\hline & Sig. (2-tailed) & .054 & .223 & .154 & .626 & .255 & & .076 & .271 \\
\hline & $\mathrm{N}$ & 60 & 60 & 60 & 60 & 60 & 60 & 60 & 60 \\
\hline \multirow[t]{3}{*}{$\begin{array}{l}\text { Mean (Job } \\
\text { Rotation) }\end{array}$} & $\begin{array}{l}\text { Pearson } \\
\text { Correlation }\end{array}$ & .153 & .009 & .116 & .046 & .199 & .231 & 1 & .119 \\
\hline & Sig. (2-tailed) & .242 & .943 & .376 & .726 & .128 & .076 & & .364 \\
\hline & $\mathrm{N}$ & 60 & 60 & 60 & 60 & 60 & 60 & 60 & 60 \\
\hline \multirow{3}{*}{$\begin{array}{l}\text { Entire } \\
\text { Satisfactio } \\
\mathrm{n}\end{array}$} & $\begin{array}{l}\text { Pearson } \\
\text { Correlation }\end{array}$ & .100 & .218 & .090 & .010 & .127 & .145 & .119 & 1 \\
\hline & Sig. (2-tailed) & .447 & .094 & .495 & .939 & .334 & .271 & .364 & \\
\hline & $\mathrm{N}$ & 60 & 60 & 60 & 60 & 60 & 60 & 60 & 60 \\
\hline
\end{tabular}

The correlation coefficients between the identified lean practices such as Empowerment, Standerdization, Effort Reward Faireness, Team Working Culture and Employees' Job Satisfaction are statistically significant and they are also indicating a positive linear relationship as mentioned in above table $(r=0.752, r=0.710, r=0.827, r=0.745$ $\mathrm{p}<.000$ ). It's positive relationship indicates the strength and the direction of the two variables.But when it is considered the correlation coefficient between the quality management and job satisfaction, it indicates a moderate positive relationship as shown in above table $(r=0.510)$. The correlaion coefficient between the job rotation and job satisfaction indicates the negative relationship as shown in above table(0.119).

Table 7. Model Summary of Correlaion

\begin{tabular}{|c|c|c|c|c|c|c|c|c|c|c|}
\hline \multicolumn{11}{|c|}{ Model Summary } \\
\hline \multirow{2}{*}{$\begin{array}{l}\text { M } \\
\text { od } \\
\text { el }\end{array}$} & \multirow[t]{2}{*}{$\mathrm{R}$} & \multirow{2}{*}{$\begin{array}{c}\mathrm{R} \\
\text { Squa } \\
\text { re }\end{array}$} & \multirow{2}{*}{$\begin{array}{l}\text { Adjusted } \\
\text { R Square }\end{array}$} & \multirow{2}{*}{$\begin{array}{l}\text { Std. Error } \\
\text { of the } \\
\text { Estimate }\end{array}$} & \multicolumn{5}{|c|}{ Change Statistics } & \multirow{2}{*}{$\begin{array}{l}\text { Durb } \\
\text { in-W } \\
\text { atson }\end{array}$} \\
\hline & & & & & $\begin{array}{c}\mathrm{R} \\
\text { Square } \\
\text { Change }\end{array}$ & $\begin{array}{c}\text { F } \\
\text { Change }\end{array}$ & df1 & df2 & $\begin{array}{l}\text { Sig. F } \\
\text { Change }\end{array}$ & \\
\hline 1 & $.746^{\mathrm{a}}$ & .520 & .502 & .45722 & .120 & 1.013 & 7 & 52 & .433 & .817 \\
\hline \multicolumn{11}{|c|}{$\begin{array}{l}\text { a. Predictors: (Constant), Job Rotation, Problem Solving Demand, Standardization, Effort Reward Fairness, } \\
\text { Empowerment, Quality Management, Team Working Culture }\end{array}$} \\
\hline
\end{tabular}

Multiple correlation " $\mathrm{R}$ " is 0.746 . It indicates that there is a strong positive linear relationship between the lean practices and employee satisfaction. R-square is 0.520 . This indicates that $52 \%$ of -job satisfaction has been described by the lean practices. Adjusted R-square is also representing that $50.2 \%$ of the job satisfaction has been described by the lean practices. As the value is more than $50 \%$, the regression model is well fitted. This table indicates that the regression model predicts the job satisfaction significantly well. "Sig." column indicates the statistical significance of the regression model that was run. Here, $\mathrm{p}<0.0005$, which is less than 0.05 , and indicates that, overall, the regression model statistically significantly predicts the outcome variable.

\section{Conclusion}

Employees are the backbone of every organization, without employees no work can be done. When the attitude of the employee towards his or her job is positive, there is job satisfaction or negative there exists job dissatisfaction. Job satisfaction gives less work stress, cheerful and positive approach, whereas job dissatisfaction gives dejection, disappointment or even depression. One of the main challenges facing by Sri Lankan apparel manufacturing firms is the existence of higher labor turnover in relation to the labor recruitments. Some of the leading apparel companies have applied the lean concepts into their operations causing the significant impact on the job role of employees. The ABC apparel firm is also one of the leading apparel manufacturing firm adhering to lean industrial environment. The main lean concepts practiced in the ABC firm are Empowerment, Standardization, Quality Concerns Problem Solving Demand, Reward System, Team Working Culture and Job Rotation. With the survey result, it can be identified that, lean practices have significantly changed the industrial environment and employee job satisfaction. 
Among the selected participant $66.6 \%$ of employees have accepted the fact that lean practices have increased their job satisfaction. Less no of employees have disagreed with the given statements. But when it is considered the demographic data of the disagreed employees, they have less working experience with the company. Among the lean practices, Empowerment, Standardization, Reward System, Team Working Culture are the practices which positively impact on the employee job satisfaction. Due to some lean practices such as problem solving demand, quality management and job rotation, employees' job satisfaction have been decreased. In the quality management procedures, they have to follow-up the excess work load in addition to assigned work. Some employees may feel uncomfortable when they have to explain their suggestions about the identified problem. In the job rotation procedure, some employees don't like to take different duties \& responsibilities. Therefore appropriate actions need to be taken in order to minimize the negative impact of lean implementation on the job satisfaction. Therefore it can be concluded that there is a moderate positive relationship exist between lean implementation and job satisfaction.

\section{Limitations \& Future Work}

Several limitations exist in this study. The data was limited to a single manufacturing plant. Just as with any case study, one cannot simply generalize the results obtained here to other companies. This research, nonetheless, does provide some insights into the possible effects of switching to lean production in the face of increased competition. The primary contribution of this research is the identification of the lean practices that have been integrated with the human resource practices for improving job satisfaction while enhancing the organizational goals. As a future work, a survey can be conducted covering all other apparel manufacturing plants which have implemented the lean practices in order to generalize the impact of lean implementation on job satisfaction.

\section{References}

Aziri, B. (2011). Job Satisfaction: A Literature Review. Management Research And Practice, 3(4), 77-86. Tetovo, Makedonia: Faculty of Business and Economics, South East European University, Ilindenska 1200.

Bonavia, T., \& Marin-Garcia, J. A. (2011). Integrating human resource management into lean production and their impact on organizational performance. International Journal of Manpower, 17. https://doi.org/10.1108/01437721111181679

Bouville, G., \& Alis, D. (2014). The effects of lean organizational practices on employees' attitudes and workers' health: evidence from France. International Journal of Human Resource Management, 44. https://doi.org/10.1080/09585192.2014.951950

Boztınaztepe, B. (2008). Lean Tools for Reducing Production Time and Satisfying - A Case Study. vVäxjö University.

Byfuglien, J., Torstensen, H., Trolie, A., \& Norway, S. (2010). The improvement of HR management by using Lean, (pp. 7).

Cullinane, S. J. (2012). Job design under lean manufacturing and its impact on employee outcomes. Organizational Psychology Review, 21. Dublin City University, Ireland. https://doi.org/10.1177/2041386612456412

De Silva, K., Peelikumbura, P., Gunathilaka, S., \& Jayawardena, H. M. G. L. (2016). Applicability of Lean Concept in Improving the Human Resourcing Practice in the Context of Sri Lankan Apparel Industry. 3rd International HR Conference, (p. 10). Department of Human Resource Management, University of Sri Jayewardenepura.

Vani, U., \& Janani, P. M. (2016). Job Satisfaction Of Garment Workers In Textile Unit With Special Reference To Dhikksha Exports, Tirupur. International Journal of Research in IT \& Management, 9.

Grobelny, A. L., \& Ewelina, P. (2012). Readiness for change and job satisfaction in a case of lean management application - A comparative study. International Journal of Occupational Medicine and Environmental Health, 9.

Huda, S. S., Akhtar, N., \& Akhtar, A. (2011). Employee's View on Job Satisfaction: A Study on Garments Industry in Bangladesh. Indus Journal of Management \& Social Sciences, 5(1), 1-9,

Gamage, J. R., Vilasini, P. P. G. N., Perera, H. S. C., \& Wijenatha, L. (2012). Impact of Lean Manufacturing on Performance and Organisational Culture: A Case Study of an Apparel Manufacturer in Sri Lanka, (pp. 15). Research Gate. https://doi.org/10.32738/CEPPM.201209.0040

Martínez-Juradoa, P. J., Moyano-Fuentesa, J., \& PilarJerez-Gómezb. (2013). Human resource management in 
Lean Production adoption and implementation processes: Success factors in the aeronautics industry. $B R Q$ Business Research Quarterly, 17(1), 47-63. ElsevierEspaña.

Minh, K. S. (2012). Companies, Impact of Lean Manufacturing Practices on Job Satisfaction Among Employees in Lean Manufacturing; Characteristics, Moderated By Lean Culture And Mediated By Job. Malaysia: Khaw Sui Minh.

Rodríguez, D. (2015). The effect of Lean on job satisfaction: An experimental approach.

Shukla, K. A. S. (2016). To Study the Factors Affecting the Job Satisfaction and Level of Job Satisfaction at Baswara Garments Ltd. The International Journal of Indian Psychology, 15.

Sim, K. L., Curatola, A. P., \& Banerjee, A. (2015). Lean Production Systems and Worker Satisfaction. Advances in Business Research, 22.

Vidal, M. (2007). Lean Production, Worker Empowerment,and Job Satisfaction: A Qualitative Analysis. Critical Sociology, 33, 32. https://doi.org/10.1163/156916307X168656

\section{Copyrights}

Copyright for this article is retained by the author(s), with first publication rights granted to the journal.

This is an open-access article distributed under the terms and conditions of the Creative Commons Attribution license (http://creativecommons.org/licenses/by/4.0/). 